Vol. 11 (11), pp. 385-393, November 2017

DOI: 10.5897/AJPS2017.1579

Article Number: CF5B30A66450

ISSN 1996-0824

Copyright (C) 2017

African Journal of Plant Science

Author(s) retain the copyright of this article

http://www.academicjournals.org/AJPS

\title{
Correlation between seed characteristics and biomass production of Moringa oleifera provenances grown in Ouagadougou, Burkina Faso
}

\author{
Madjelia Cangré Ebou Dao ${ }^{1^{*}}$ and Denis Walsh ${ }^{2}$ \\ ${ }^{1}$ Institut de l'Environnement et de Recherches Agricoles (INERA), 04 BP 8645 Ouagadougou, Burkina Faso. \\ ${ }^{2}$ Université du Québec à Chicoutimi (UQAC), 555 Boul. de l'Université, Chicoutimi, Québec, Canada.
}

Received 15 June, 2017; Accepted 13 October, 2017

\begin{abstract}
The correlation between seed size and biomass production of Moringa oleifera, was conducted in a field experiment at Ouagadougou (Burkina Faso) in 2014. The experiment included eleven M. oleifera provenances from West Africa according to four agro-ecological characteristics (Sahelian, Sub Equatorial, South Sudanian and North Sudanian). Differences among provenances seed traits, leaf morphology, and dry mass (DM) were established by analyses of variance. Significant level was fixed at $P<0.05$. Pearson's correlation analysis was done to evaluate the relationships between seed traits, leaf morphology, and dry mass. The results showed that significant differences in seed traits were observed among provenances. Provenances were significantly different in leaf morphology (length, width and number of pinnae/seedling). The provenance of National Forest Seed Center (CNSF) from the northern sudanese area of Burkina Faso produced the longest leaf. The mean shoot biomass accumulation per seedling differed significantly among provenances. Significant correlation coefficients were observed among seed traits but no important correlation were found between seed traits and other plant characteristics. No significantly correlation of seed size with either leaf morphology or dry mass were found. Plant grown from large seeds compared to those grown from small seeds was more vigorous and produces greater dry matter.
\end{abstract}

Key words: Moringa seedling, dry biomass, correlation, seed length, seed weight, seed width.

\section{INTRODUCTION}

There are many trees and shrubs of interest in agroforestry systems, and one interesting tree species that has received a great deal of attention recently is Moringa oleifera Lam (Mendieta-Araica et al., 2013). The species is planted to produce pods, leaves and seeds for consumers, forage and traditional medicinal purposes. The pods and leaves of $M$. oleifera contains high amount of $\mathrm{Ca}, \mathrm{Mg}, \mathrm{K}, \mathrm{Mn}, \mathrm{P}, \mathrm{Zn}, \mathrm{Na}, \mathrm{Cu}$ and $\mathrm{Fe}$ (Aslam et al., 2005).

In Burkina Faso, M. oleifera leaves are commonly used

*Corresponding author. E-mail: mamadjelia@yahoo.com.

Author(s) agree that this article remains permanently open access under the terms of the Creative Commons Attribution License 4.0 International License 
to make sauces and as staple food. Cultivations of $M$. oleifera within different environmental conditions throughout the year attract attention of poor smallholders during the last years (Popoola and Obembe, 2013). Biomass productions and seeds yield are of key economic importance. Some smallholders in Burkina Faso formed the associations of women nursery operators engaged in seedlings productions for income generation with the objective of selling the seedlings. They have been found to exchange most of the $M$. oleifera seeds often collected from a few mother isolated trees in their farmlands, and plantations in the communities or outside.

This way of supplying seeds by private producers limited the access to high quality germplasm (Nyoka et al., 2015). M. oleifera plants were promoted within smallholders by many non governmental organisations (NGOs) and government, but no varieties with desirable traits for specifics growing conditions (home gardens, farmlands) are available, which makes its cultivation a risky business.

Good seedling establishment is essential for sustainable and profitable crop production, and is therefore recognized as the most critical step of a developing plant. Low seed vigor greatly controls the number of emerging seedlings, the timing and uniformity of seedling growth. This has direct influence on the yield and marketing quality of a crop (Pallo et al., 2009).

Seed weight is an indication of the reserves that seeds contain, and large and heavy seeds reveal that the seed has more reserved food (Wolde-Mieskel and Sinclair, 2000). Many studies have shown that initial seedling size is positively related to seed size, and larger seeds have better seedling survival rate as well as higher competitiveness both within species and among species (Singh et al., 2006). The seed supplies the embryo with sufficient nutrition and energy during germination from the food reserves that the seed acquires during the seed filling phase. Roxas et al. (1994) concluded that higher vigor that occurred in larger seed is due to the larger food reserves in these seeds.

Many studies also indicated a positive linear relationship between seed weight and emergence in the field. Baalbaki and Copeland (1997) reported that in wheat, seed size not only influence emergence and establishment but also affected yield components and ultimately grain yield. A similar observation was made by Arunachalam et al. (2003), while working with the tree species, and this was attributed to the larger food reserves in the larger seeds.

Several studies have been conducted looking for $M$. oleifera growth performance and biomass production (Edward et al., 2014; Förster et al., 2015), biomass production and chemical composition (Mendieta-Araica et al., 2013), seed and germination characteristics. There are however limited studies on the explicit relationship among seed and biomass characteristics.
In addition, the multivariate analyses have been widely used to study the influence of interacting traits on fitness in plant ecology studies (Farris and Lechowicz, 1990), assess plant responses to environmental stress (Hofmann et al., 2013), and examine morphological variation in agricultural crops (Ayana and Bekele, 1999).

The objective of this study was to investigate and compare different growth characters among provenances of $M$. oleifera in smallholders gardening systems. Seed length, width weight, leaf size and shape, and branch number may be useful predictors of potential production in specific environments (Pellis et al., 2004; Weih and Nordh, 2005). The relationships between seed characteristics and biomass production of $M$. oleifera in north sudanian part of Burkina Faso were therefore investigated.

\section{MATERIALS AND METHODS}

\section{Location of experimental area}

The study was carried out at the women gardening center named "Amicale des Forestières du Burkina Faso (AMIFOB)" located at Ouagadougou, Burkina Faso $\left(12^{\circ} 7^{\prime} 32^{\prime \prime} \mathrm{N}, 01^{\circ} 40^{\prime} 24^{\prime \prime} \mathrm{W}\right)$. This corresponds to an ecological zone of the north sudanian forest, with average annual rainfall of $800 \mathrm{~mm}$. The soils are sandy clay to claysandy Ferruginous leached with very low nutrient content according to French soil classification (Pallo e al., 2009). The common natural vegetation found at Ouagadougou is described as semi-deciduous open woodland. Main genera include, Eucalyptus, Azadirachta, Mangifera, Vitellaria, Lannea, Piliostigma, Acacia., Ziziphus, Tamarindus, and Combretum.

\section{Seed sources}

The experiment included twelve $M$. oleifera provenances which include 1 provenance of from Segou (Mali), 1 from Niangon-Lokoua (Ivory Coast), 1 from Tamale (Ghana) and 9 from Burkina Faso (Ouahigouya, Dano, Gaoua, Ouagadougou, Fada N'Gourma, Dédougou, Bobo-Dioulasso, Koudougou, Centre National de Semences Forestières (CNSF) (Figure 1). In the paper, provenances were referred to four climate areas according to their agro-ecological characteristics (Sahelian, Sub Equatorial, South Sudanian and North Sudanian) (Table 1). Seeds were collected in 2014 in plantation farmland from at least 12 mother trees per provenance.

\section{Experimental design and sampling procedures}

Trees were planted in a randomized complete block design (RCBD) with three replications. Each plot represented a provenance planted at $5 \times 6$ rows in a contiguous arrangement of $20 \times 20 \mathrm{~cm}$ (Figure 2). Plot measured $10 \times 1 \mathrm{~m}$ and contained 30 trees, and the distances between blocks were $2 \mathrm{~m}$. Seed samples were pretreated with water for $24 \mathrm{~h}$, and sown in June 1st 2014 in a prepared and cleaned soil using hand hoes. Weeding was done twice during the rainy season. Watering was done once a day in the morning. The seedlings were grown without fertilizers and chemical control.

\section{Data collection and analysis}

To investigate the variability in seed parameters (length, thickness, 


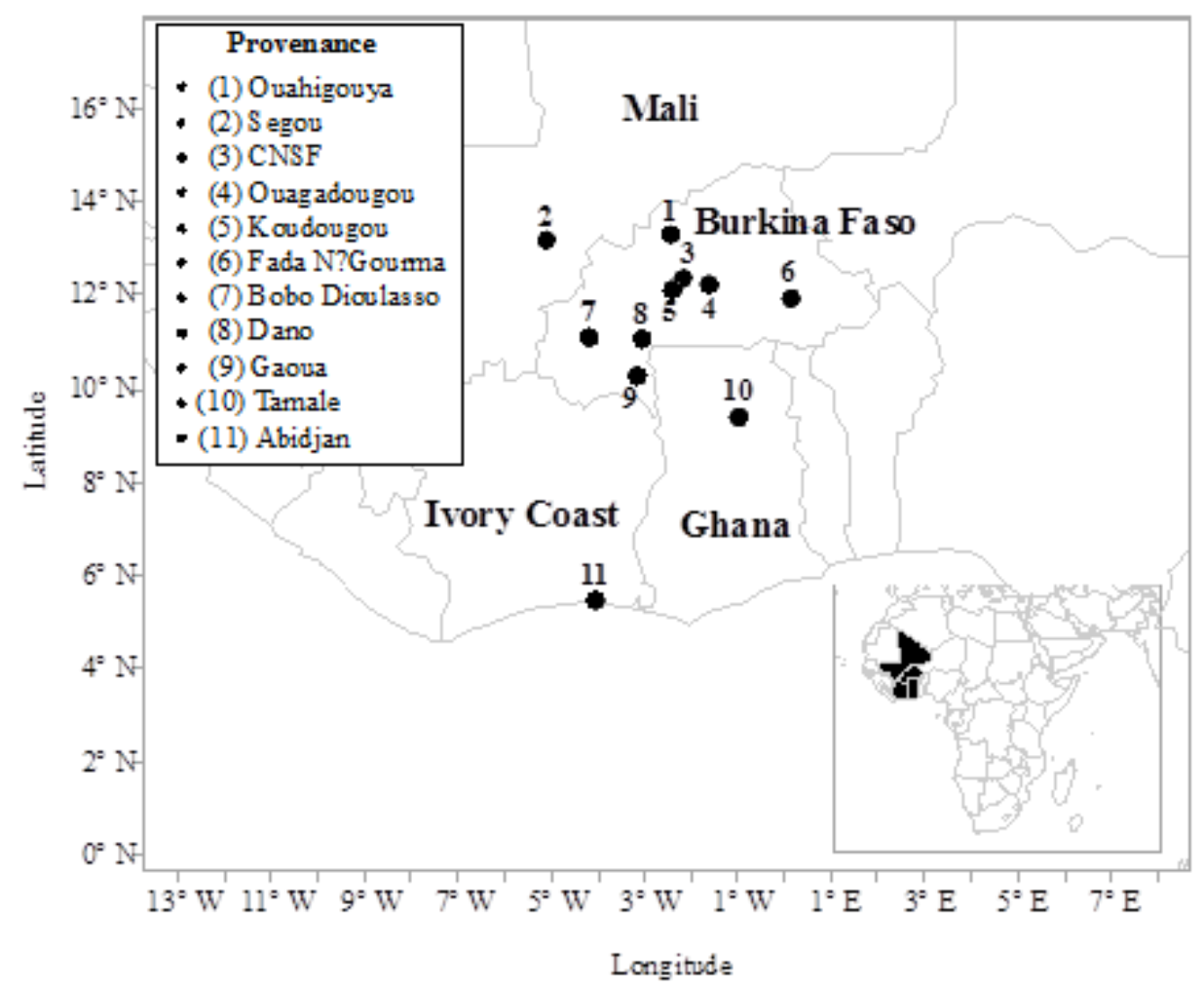

Figure 1. Provenance location.

Table 1. Location and other attributes of the M. oleifera provenances.

\begin{tabular}{|c|c|c|c|c|c|c|c|c|}
\hline Prov. code & Ecological Zone & Provenance & Country & Latitude & Longitude & Altitude (m) & Average rainfall (mm/year) & Mother trees number \\
\hline 1 & Sahelian & Ouahigouya & Burkina Faso & $13^{\circ} 30^{\prime} 4^{\prime \prime} \mathrm{N}$ & $2^{\circ} 24^{\prime} 31^{\prime \prime} \mathrm{W}$ & 306 & 500 & 24 \\
\hline 2 & North Sudanian & Segou & Mali & $13^{\circ} 22^{\prime} 05^{\prime \prime} \mathrm{N}$ & $5^{\circ} 16^{\prime} 24^{\prime \prime}$ & 294 & 500 & 35 \\
\hline 3 & North Sudanian & CNSF & Burkina Faso & $12^{\circ} 30^{\prime} 07 \mathrm{~N}$ & $2^{\circ} 07^{\prime} 34^{\prime \prime} \mathrm{W}$ & 304 & 800 & 35 \\
\hline 4 & North Sudanian & Ouagadougou & Burkina Faso & $12^{\circ} 21^{\prime} 58^{\prime \prime} \mathrm{N}$ & $1^{\circ} 31^{\prime} 05^{\prime \prime} \mathrm{W}$ & 315 & 800 & 15 \\
\hline 5 & North Sudanian & Koudougou & Burkina Faso & $12^{\circ} 15^{\prime} 04^{\prime \prime} \mathrm{N}$ & $2^{\circ} 22^{\prime} 28^{\prime \prime} \mathrm{W}$ & 308 & 800 & 12 \\
\hline 6 & North Sudanian & Fada N'Gourma & Burkina Faso & $12^{\circ} 03^{\prime} 41^{\prime \prime} \mathrm{N}$ & $0^{\circ} 21^{\prime} 30 " \mathrm{E}$ & 300 & 900 & 26 \\
\hline 7 & Sudanian & Bobo Dioulasso & Burkina Faso & $11^{\circ} 11^{\prime} 00^{\prime \prime} \mathrm{N}$ & $4^{\circ} 17^{\prime} 00^{\prime \prime W}$ & 339 & 950 & 20 \\
\hline 8 & Sudanian & Dano & Burkina Faso & $11^{\circ} 9^{\prime} \mathrm{O}^{\prime \prime} \mathrm{N}$ & $3^{\circ} 4^{\prime} \mathrm{O}^{\prime \prime} \mathrm{W}$ & 287 & 950 & 30 \\
\hline 9 & Sudanian & Gaoua & Burkina Faso & $10^{\circ} 19^{\prime} 12^{\prime \prime} \mathrm{N}$ & $3^{\circ} 10^{\prime} 12^{\prime \prime W}$ & 319 & 1000 & 17 \\
\hline 10 & Sudanian & Tamale & Ghana & $9^{\circ} 24^{\prime} 27^{\prime \prime} \mathrm{N}$ & $00^{\circ} 51^{\prime} 12 " \mathrm{~W}$ & 169 & 1100 & 15 \\
\hline 11 & Sub-Equatorial & Abidjan & Ivory Coast & $5^{\circ} 18^{\prime} 28 " \mathrm{~N}$ & $4^{\circ} 6^{\prime} 19^{\prime \prime W}$ & 73 & 2000 & 18 \\
\hline
\end{tabular}

and weight), each provenance was represented by 240 randomly selected seeds, assessed in four replications of 60 seeds each. Each seed weight was determined by weighing three random samples of 60 seeds each. By the end of 2 weeks; the experiment had been measured twice at effective ages of 5 and 12 days since seed sowing, providing data for the assessment of germination rates of the twelve provenances. Total samples of 20 seedlings per replication for each provenance were assessed. The seedlings were separated into shoot and root components that were ovendried for $48 \mathrm{~h}$ at $70^{\circ} \mathrm{C}$, and weighed to determine total dry weight and calculation of root-to-shoot ratios. Height was measured using calibrated height measuring pole. Differences among provenances seed traits, leaf morphology, and dry mass (DM) were established by analyses of variance (ANOVA) using the Linear Model procedure (Standard Least Squares option) of the JMP® Pro 12.0.1 statistical software package (SAS Institute Inc., Cary, NC). Normality and homoscedasticity were graphically verified on residual plots of the linear models (Quinn and Keough, 2002). Where the ANOVA indicated significant treatment effects, treatment means were separated by Tukey's Honestly Significant Difference (HSD) test ( $p$ $=0.05$ ). Pearson's product- moment correlation analysis was done to evaluate the relationships between the studied traits (Seed weight, distance, thickness; Leaf length, width, pinna number; base, shoot, total, root/shoot dry mass). The provenance relationships 


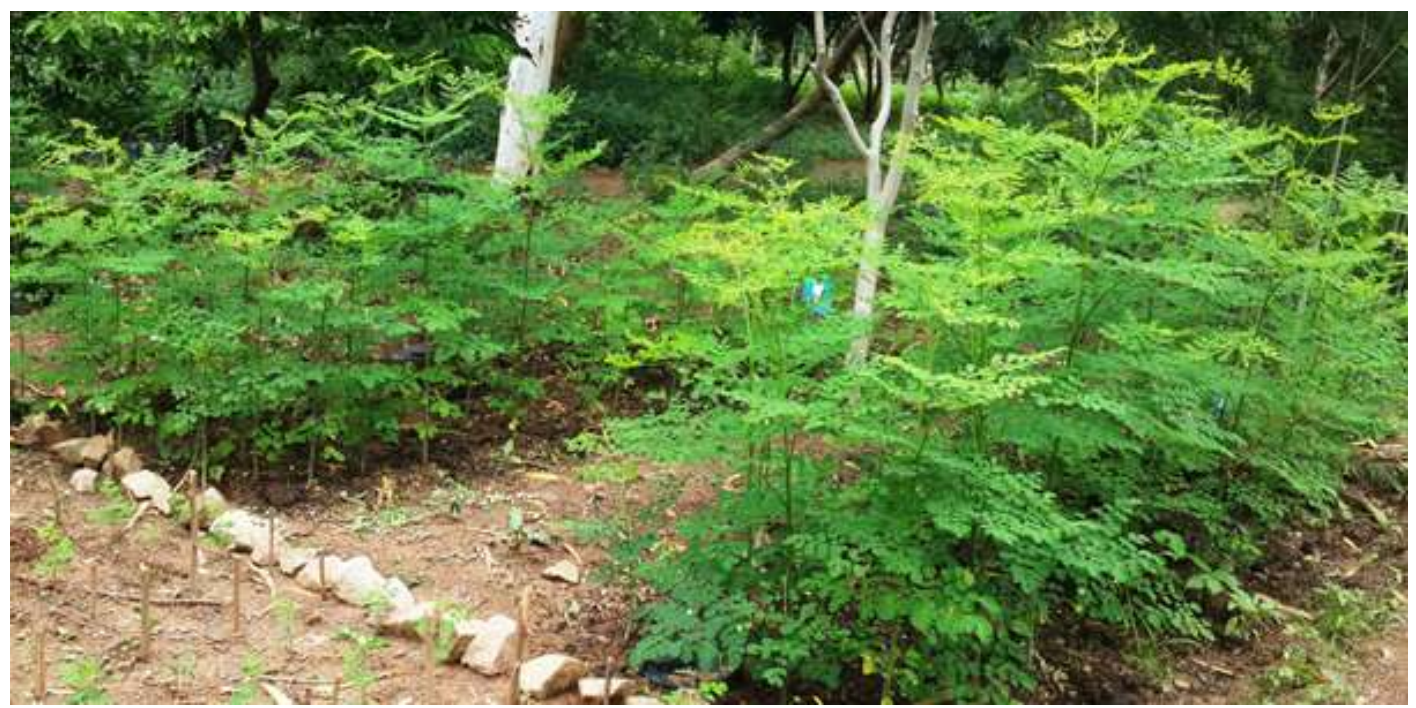

Figure 2. Moringa's plots.

("similarity") were examined on the basis of the 10 traits used in the correlation analysis by a hierarchical cluster analysis using the JMP® Pro Cluster Analysis from the Multivariate methods submenu, which applies the "Ward distance" (SAS Institute Inc., 2012).

\section{RESULTS}

\section{Seed characteristics}

Significant differences $(P<0.05)$ in seed traits (length, width and thickness) were observed among provenances (Table 2). Mean seed length ranged from 12 to $16 \mathrm{~mm}$ for Koudougou, and the longest provenance Fada N'Gourma, respectively (Table 2). Similarly, mean weight at the same time ranged from 1 to $2 \mathrm{~g}$ for provenances Fada N'Gourma -Koudougou and for provenances Gaoua- Ouahigouya respectively (Table 2). Seed thickness ranged from 10 to $11 \mathrm{~mm}$ for provenances Koudougou-Bobo Dioulasso and provenances Ouahigouya-Ouagadougou, Segou-Gaoua-Abidjan, respectively.

\section{Leaf morphology and dry biomass production}

Provenances were significantly different $(P<0.05)$ in leaf morphology (length, width and number of pinnae/seedling) (Table 2). Among 11 provenances, CNSF produced the longest leaf $(45 \mathrm{~mm})$ compared with $17 \mathrm{~mm}$ for Bobo Dioulasso. Ouahigouya, Segou, Ouagadougou, Koudougou, Koudougou, Fada N'Gourma, Dano, Gaoua, Tamalé and Abidjan were in the middle of the range. Mean leaf width ranged from 34 to $105 \mathrm{~mm}$ for Tamalé and CNSF, respectively (Table 2).
Mean number of pinnae per seedling at the same time ranged from 6 to 12 for Segou and CNSF, respectively. At the end of two months, the mean shoot biomass accumulation per seedling differed significantly $(P<0.05)$ among provenances (Table 2). The lowest shoot dry weight of $2.2 \mathrm{~g}$ was collected in provenance Bobo Dioulasso, while the highest of $21.4 \mathrm{~g}$ was obtained in provenance Gaoua. Provenance differences in root dry biomass per seedling were considerable, with means ranging from 1.2 for $7.4 \mathrm{~g}$ for Tamalé and Gaoua, respectively (Table 2). Mean shoot ranged from 1.2 to $14.0 \mathrm{~g}$ for Bobo Dioulasso and Gaoua, respectively (Table 2). Similarly, total dry mass produced at the same time ranged from 2.2 to $21.4 \mathrm{~g}$ for Bobo Dioulasso and Gaoua, respectively. The ratio root: shoot dry mass ranged from 0.4 to $0.9 \mathrm{~g}$ for Dano and Tamalé, respectively.

\section{Interdependence among characters}

Significant positive Pearson's product-moment correlation coefficients ( $r$ ) were observed among seed traits but no important correlation were found between seed traits and other plant characteristics (Table 3 ). Traits related to seed size (length, width, and weight) were mostly correlated with each other, Seed weight was positively correlated with seed length $(r=0.28)$, and seed thickness $(r=0.3)$. Seed length was positively related with seed thickness $(r=0.23)$. No significantly correlation of seed size with either leaf morphology or dry mass. An exception to the trend was seed thickness with leaf length, shoot dry biomass and total dry mass, which displayed a weak magnitude of the correlation coefficients $(r<0.20)$. Significant relationships were also detected between traits related to leaves morphology, 


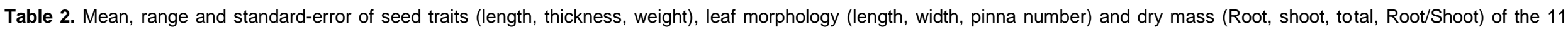
provenances of $M$. oleifera.

\begin{tabular}{|c|c|c|c|c|c|c|c|c|c|c|}
\hline \multirow[b]{2}{*}{ Provenance } & \multicolumn{3}{|c|}{ Seed } & \multicolumn{3}{|c|}{ Leaf } & \multicolumn{4}{|c|}{ Dry mass } \\
\hline & $\begin{array}{c}\text { Length } \\
\text { (mm) }\end{array}$ & $\begin{array}{c}\text { Thickness } \\
\text { (mm) }\end{array}$ & $\begin{array}{l}\text { Weight } \\
\text { (g) }\end{array}$ & $\begin{array}{c}\text { Length } \\
(\mathrm{mm})\end{array}$ & $\begin{array}{l}\text { Width } \\
(\mathrm{mm})\end{array}$ & $\begin{array}{c}\text { Pinna } \\
\text { number }\end{array}$ & $\begin{array}{c}\text { Root } \\
\text { (g) }\end{array}$ & $\begin{array}{c}\text { Shoot } \\
(\mathrm{g})\end{array}$ & $\begin{array}{c}\text { Total } \\
\text { (g) }\end{array}$ & $\begin{array}{c}\text { Root/Shoot } \\
(\mathrm{g} / \mathrm{g})\end{array}$ \\
\hline \multirow{2}{*}{ Ouahigouya } & $15^{\mathrm{ab}}$ & $11^{a}$ & $2^{a}$ & $29^{\mathrm{de}}$ & $65^{\mathrm{de}}$ & $9^{c}$ & $2.2^{\text {cde }}$ & $4.0^{\operatorname{def}}$ & $6.2^{\text {def }}$ & $0.5^{\mathrm{b}}$ \\
\hline & $12-17$ & $10-12$ & $1.5-2.0$ & $21-38$ & $46-104$ & $7-12$ & $0.5-13.4$ & $1.8-10.1$ & $2.9-20.4$ & $0.2-1.9$ \\
\hline \multirow{2}{*}{ Segou } & $14^{\mathrm{bc}}$ & $11^{\mathrm{a}}$ & $2^{\mathrm{ab}}$ & $22^{\mathrm{ef}}$ & $50^{\text {ef }}$ & $6^{d}$ & $1.8^{\mathrm{cde}}$ & $3.4^{\text {ef }}$ & $5.2^{\text {ef }}$ & $0.5^{\mathrm{ab}}$ \\
\hline & $12-17$ & $10-13$ & $1.3-2.0$ & $12-29$ & $29-74$ & $5-8$ & $0.1-4.5$ & $0.6-7.3$ & $0.7-9.3$ & $0.2-1.6$ \\
\hline \multirow{2}{*}{ CNSF } & $15^{\mathrm{ab}}$ & $10^{\mathrm{bc}}$ & $2^{\mathrm{bc}}$ & $45^{\mathrm{a}}$ & $105^{\mathrm{a}}$ & $12^{a}$ & $5.8^{\mathrm{abc}}$ & $12.2^{\mathrm{ab}}$ & $18.0^{\mathrm{abc}}$ & $0.5^{\mathrm{b}}$ \\
\hline & $12-17$ & $9-12$ & $1.4-1.9$ & $28-62$ & $65-178$ & $8-15$ & $2.2-17.6$ & $4.9-21.5$ & $8.1-39.1$ & $0.3-1.3$ \\
\hline \multirow{2}{*}{ Ouagadougou } & $13^{\mathrm{cd}}$ & $11^{\mathrm{a}}$ & $2^{\mathrm{ab}}$ & $43^{a}$ & $101^{a}$ & $11^{\mathrm{abc}}$ & $6.6^{\mathrm{abc}}$ & $11.6^{\mathrm{ab}}$ & $18.2^{\mathrm{ab}}$ & $0.6^{\mathrm{ab}}$ \\
\hline & $12-15$ & $10-13$ & $1.5-2.0$ & $34-63$ & $60-150$ & $6-14$ & $0.8-25.4$ & $5.1-27.9$ & $6.0-51.3$ & $0.2-1.6$ \\
\hline \multirow[t]{2}{*}{ Koudougou } & $12^{d}$ & $10^{\mathrm{cd}}$ & $1^{d}$ & $33^{\mathrm{cd}}$ & $74^{\mathrm{cd}}$ & $10^{c}$ & $4.5^{\mathrm{abcde}}$ & $6.3^{\text {cde }}$ & $10.7^{\text {cde }}$ & $0.7^{\mathrm{ab}}$ \\
\hline & $11-15$ & $9-11$ & $1.1-1.6$ & $26-42$ & $53-103$ & $8-12$ & $1.5-23.3$ & $3.0-16.9$ & $4.7-30.4$ & $0.4-3.3$ \\
\hline \multirow{2}{*}{$\begin{array}{l}\text { Fada } \\
\text { N'Gourma }\end{array}$} & $16^{a}$ & $11^{\mathrm{ab}}$ & $1^{d}$ & $39^{\mathrm{abc}}$ & $86^{\mathrm{abc}}$ & $11^{\mathrm{abc}}$ & $5.3^{\mathrm{abc}}$ & $10.2^{\mathrm{abc}}$ & $15.5^{\mathrm{abc}}$ & $0.5^{\mathrm{ab}}$ \\
\hline & 13-18 & $10-12$ & $1.0-1.8$ & $30-55$ & $63-122$ & $7-14$ & 1.9 & $3.8-25.1$ & $7.0-33.4$ & $0.3-1.4$ \\
\hline \multirow{2}{*}{ Bobo Dioulasso } & $13^{\mathrm{cd}}$ & $10^{\mathrm{cd}}$ & $1^{\mathrm{cd}}$ & $17^{\dagger}$ & $35^{f}$ & $7^{d}$ & $18.1^{\mathrm{e}}$ & $1.2^{f}$ & $2.2^{\dagger}$ & $0.8^{\mathrm{ab}}$ \\
\hline & $11-16$ & $9-11$ & $1.0-2.0$ & $8-26$ & $16-59$ & $4-9$ & $0.1-4.2$ & $0.2-3.0$ & $0.3-5.6$ & $0.2-3.0$ \\
\hline \multirow{2}{*}{ Dano } & $13^{\mathrm{cd}}$ & $11^{\mathrm{ab}}$ & $2^{\mathrm{bc}}$ & $41^{\mathrm{a}}$ & $92^{\mathrm{abc}}$ & $11^{\mathrm{abc}}$ & $3.1^{\text {bcde }}$ & $7.9^{\text {bce }}$ & $11.0^{\text {bcde }}$ & $0.4^{\mathrm{b}}$ \\
\hline & $11-15$ & $9-12$ & $1.4-1.9$ & $19-49$ & $42-125$ & $5-13$ & $0.4-6.3$ & $1.3-13.6$ & $1.6-19.3$ & $0.3-0.6$ \\
\hline \multirow{2}{*}{ Gaoua } & $14^{\mathrm{c}}$ & 11 & $2^{a}$ & $40^{a b}$ & $98^{a b c}$ & $11^{\mathrm{abc}}$ & $7.4^{\mathrm{a}}$ & $14.0^{\mathrm{a}}$ & $21.4^{\mathrm{a}}$ & $0.6^{\mathrm{ab}}$ \\
\hline & $13-17$ & $10-13$ & $1.6-2.0$ & $27-53$ & $74-139$ & $8-13$ & $2.7-21.2$ & $4.6-32.8$ & $7.3-43.8$ & $0.2-1.7$ \\
\hline \multirow{2}{*}{ Tamale } & $15^{\mathrm{ab}}$ & $11^{\mathrm{ab}}$ & $2^{\mathrm{ab}}$ & $18^{f}$ & $34^{\dagger}$ & $7^{d}$ & $1.2^{\mathrm{de}}$ & $1.4^{\dagger}$ & $2.6^{\dagger}$ & $0.9^{\mathrm{a}}$ \\
\hline & 12-18- & $10-12$ & $1.1-1.9$ & $12-27$ & $20-56$ & $5-11$ & $0.4-2.7$ & $0.5-2.7$ & $0.9-4.7$ & $0.4-2.4$ \\
\hline \multirow{2}{*}{ Abidjan } & $15^{\mathrm{ab}}$ & $11^{a}$ & $2^{\mathrm{ab}}$ & $34^{b c d}$ & $80^{\mathrm{bcd}}$ & $10^{\mathrm{bc}}$ & $5.2^{\text {abcde }}$ & $7.8^{\text {bcde }}$ & $12.9^{\mathrm{bcd}}$ & $0.7^{\mathrm{ab}}$ \\
\hline & $13-17$ & $11-13$ & $1.1-2.0$ & $26-49$ & $58-119$ & $7-13$ & $1.0-23.5$ & $3.5-16.7$ & $4.5-34.4$ & $0.3-2.2$ \\
\hline Standard-error & 0.3 & 0.1 & 0.04 & 1.0 & 4.0 & 0.4 & 0.9 & 1.0 & 1.6 & 0.1 \\
\hline
\end{tabular}

Mean followed by the same letter are not significantly different at the $5 \% p$ level according to Tukey's multiple comparison test. 
Table 3. Pearson correlations between seed traits, leaf morphology and dry mass.

\begin{tabular}{|c|c|c|c|c|c|c|c|c|c|c|c|}
\hline \multirow{2}{*}{ Variable } & & \multicolumn{3}{|c|}{ Seed } & \multicolumn{3}{|c|}{ Leaf morphology } & \multicolumn{4}{|c|}{ Dry mass } \\
\hline & & Weight & Length & Thickness & Length & Width & Pinna nb. & Root & Shoot & Total & Root/Shoot \\
\hline \multirow{3}{*}{ Seed } & Weight & - & - & - & - & - & - & - & - & - & - \\
\hline & Length & $0.28^{* * *}$ & - & - & - & - & - & - & - & - & - \\
\hline & Thickness & $0.3^{\star \star *}$ & $0.23^{\star \star}$ & - & - & - & - & - & - & - & - \\
\hline \multirow{3}{*}{ Leaf } & Length & 0.03 & 0.04 & $0.16^{*}$ & - & - & - & - & - & - & - \\
\hline & Width & 0.06 & 0.02 & 0.13 & $0.94^{* * *}$ & - & - & - & - & - & - \\
\hline & Pinna nb. & -0.04 & 0.06 & 0.06 & $0.82^{* * *}$ & $0.81^{* * *}$ & - & - & - & - & - \\
\hline \multirow{4}{*}{ Dry mass } & Root & 0.10 & 0.10 & 0.11 & $0.51^{* * *}$ & $0.49^{\star * *}$ & $0.43^{* * *}$ & - & - & - & - \\
\hline & Shoot & 0.09 & 0.08 & $0.15^{*}$ & $0.81^{* * *}$ & $0.82^{* * *}$ & $0.67^{\star \star *}$ & $0.64^{\star \star \star}$ & - & - & - \\
\hline & Total & 0.10 & 0.10 & $0.15^{\star}$ & $0.75^{\star * *}$ & $0.75^{\star * \star}$ & $0.63^{\star \star *}$ & $0.87^{\star \star *}$ & $0.93^{\star \star \star}$ & - & - \\
\hline & Root/Shoot & 0.01 & $<0.01$ & -0.08 & $-0.22^{\star *}$ & $-0.24^{* *}$ & $-0.19^{* *}$ & $0.49^{* * *}$ & $-0.17^{*}$ & 0.12 & - \\
\hline
\end{tabular}

${ }^{* * *}: p \leq 0.0001 ;{ }^{* *}: 0.0001<p \leq 0.01 ;{ }^{*}: 0.01<p \leq 0.05$.

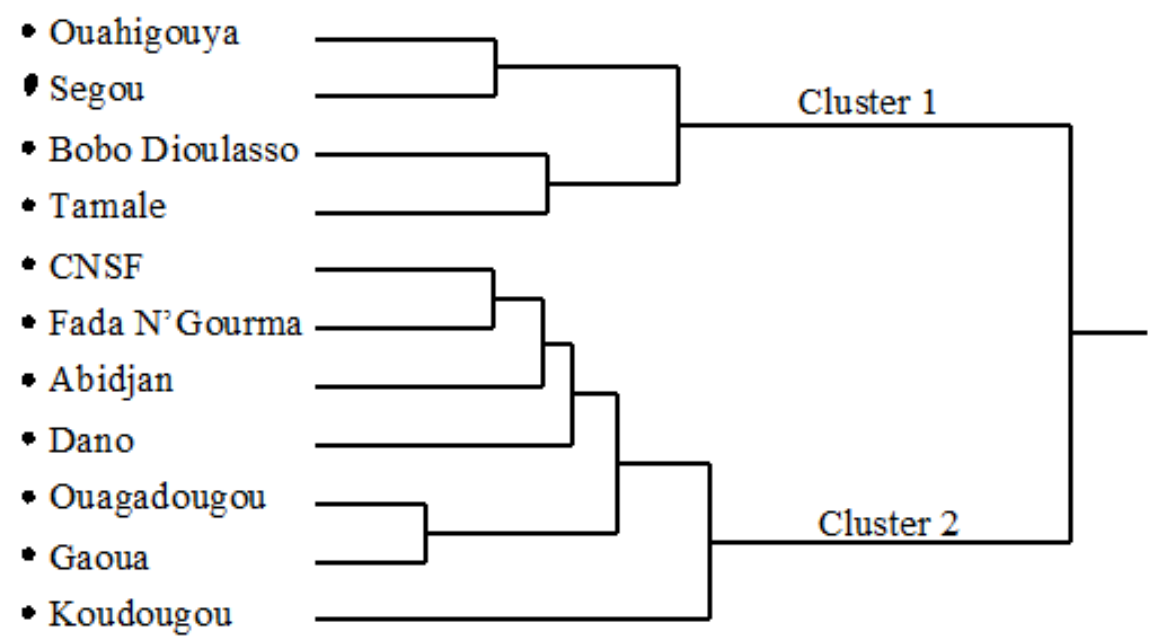

Figure 3. Hierarchical cluster dendrogram of the $11 \mathrm{M}$. oleifera provenances based on seed traits, leaf characteristics, and dry mass.

shoot and root dry biomasses. Leaf length was highly correlated with leaf width and number of pinnae $(r>0.80)$ (Table 3). Leaf morphology was positively correlated with the aforementioned while root dry mass and total dry mass $(r>0.40)$ were negatively correlated with root: shoot dry biomass (Table 3 ).

\section{Cluster analysis}

Cluster analysis based on seed sizes, leaf morphology and biomass production revealed two distinct clusters (Figures 3 and 4). Provenances Ouahigouya, Segou, Bobo-Dioulasso and Tamalé located in three different ecological zones formed cluster 1 while the seven other provenances (Dano, Ouagadougou, Fada N'Gourma,
Gaoua, Koudougou, CNSF and Abidjan), dispersed also in three different ecological zones formed the second cluster group. Provenances from cluster 1 performed high seed traits, small leaves sizes and lower biomass accumulation than cluster 2. Tamale and Bobo Dioulasso in particular, invested more biomass in root than in shoot (Figure 4). Cluster 2 had large leaves size and excellent dry biomass production.

\section{DISCUSSION}

\section{Seed}

Seed size is the main determinant of maternal investment in individual seed farmer, and it as been demonstrated 

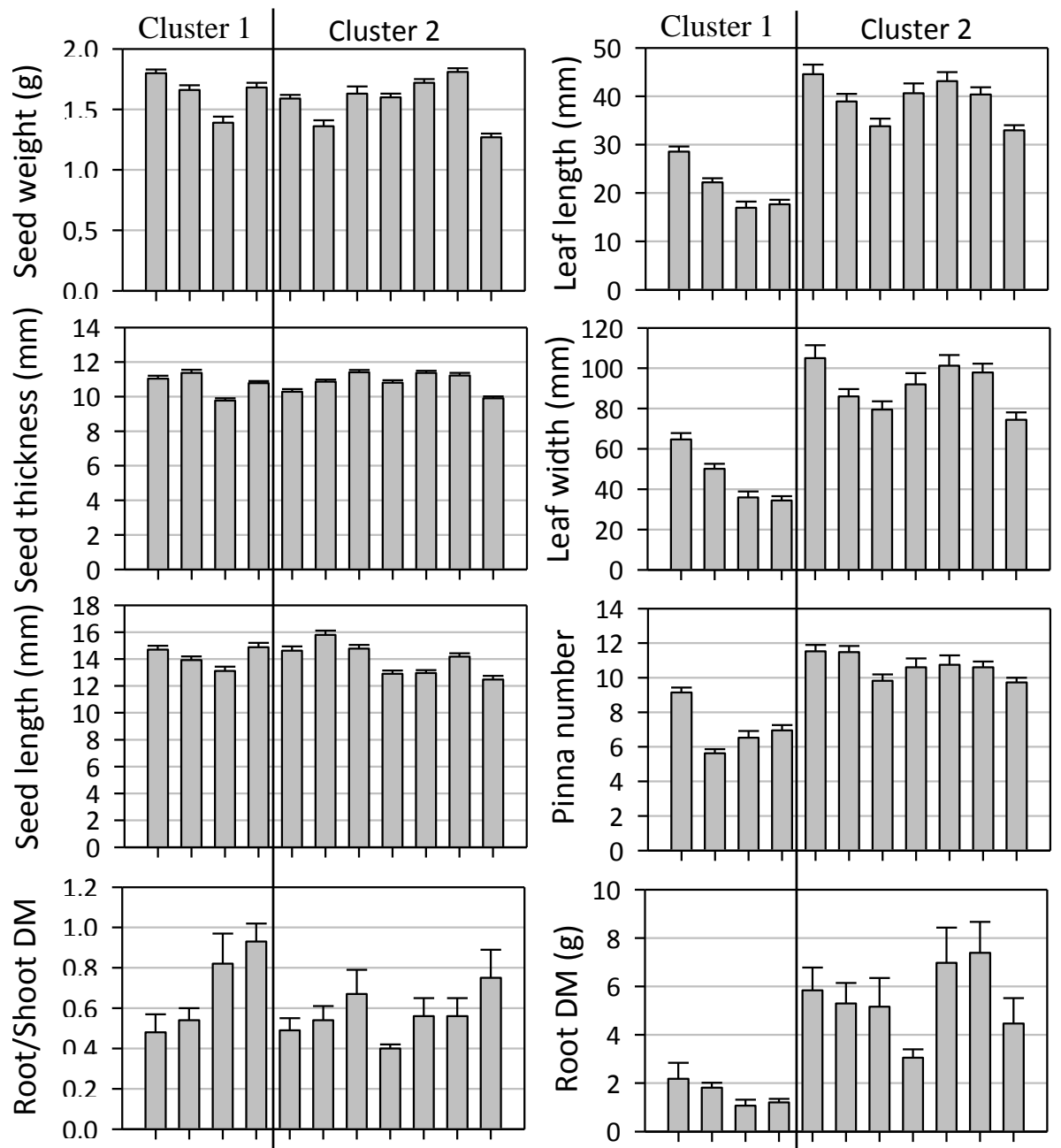

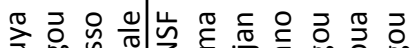

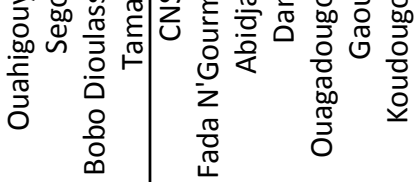

Cluster 1

Cluster 2
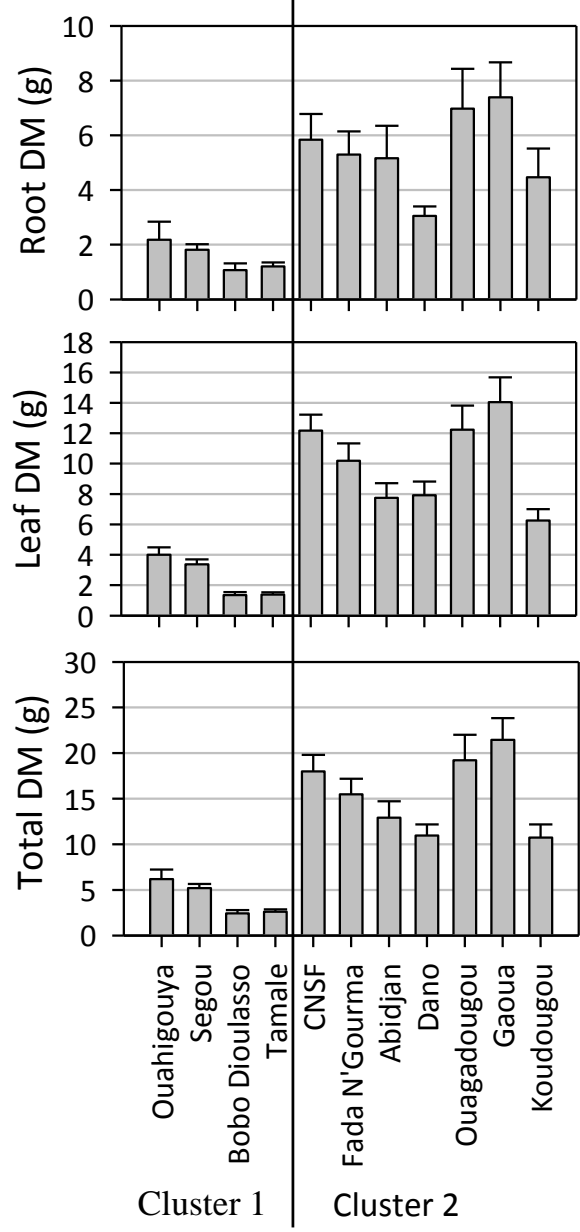

Figure 4. Mean \pm standard error of seed traits, leaf characteristics, and dry mass (DM). Provenances are grouped according to the hierarchical cluster analysis. 
that tree-to-tree variation in seed size within local populations is under relatively strong genetic. The relationship between seed size and the growth of resulting seedlings can last for about one year or up to 10 years (Farmer, 1997). Investigation of DNA markers have demonstrated that there is a large genetic diversity present in wild collections of Moringa oleifera (Shahzad et al., 2013).

The three seed traits differ significantly between provenance, specially the seed weight. Difference between the heaviest (Gaoua) and the lightest (Koudougo) was up to $43 \%$. No environemental gradient, longitude, latitude, altitude, and annual rainfall explain difference in seed traits between provenance. Grouping provenance in ecological zones did not explain either diffence in seed traits. In the opposite, the regional provenances of Faidherbia albida showed a consistent variation in seed length, seed width and seed weight: the southern African provenances had the largest seeds and west African provenances the smallest (Dangasuk et al., 1997).

According to these authors, seed weight and size are adaptive traits, their smaller mean values observed in the west African provenances might suggest strong genetic selection for small seed size which is probably an adaptation to the greater desiccation stress in the Sahelian region. In their study of provenance variation in seed size of Senegal mahogany, Ky-Dembele et al. (2014) indicate that genetic differences exist among families within provenances and provenances in seed traits of $K$. senegalensis in Burkina Faso. In contrast, the high inter- and intra-provenance variation in Moringa seed weight in this study might suggest that this parameter is quite insensitive to environmental factors.

As Moringa seed weight shows significant differences between years (Ayerza, 2011), difference in seed weight could be attributed to the year's harvest. Seed weight has little effect on acacia seedling growth in different provenances of Senegalese (Wolde-Mieskel and Sinclair, 2000), Singh et al. (2006) have found a positive correlation between morphological characters of Celtis Australis seeds, family Ulmaceae, including seed weight and elevational gradient. Provenances with heavier seed may provide seedlings that will be able to withstand the adverse climatic conditions.

\section{Growth performance}

The study results agree with those of Gamedze et al. (2012) that shows significant differences in growth performances between Moringa provenances in Swaziland. The three provenances had significant differences in the number of leaflets produced.

\section{Conclusion}

It may be concluded from this study that significant differences were found among seed traits, leaf morphology, dry diomass and provenances. The research revealed that seed size were not correlated with either leaf morphology or dry mass. However, additional studies are needed to determine factors affecting moringa yields, including potential interactions of genotypexenvironment on seed per tree production, before making any recommendation about the economic potential of moringa as a new crop for this region.

\section{CONFLICT OF INTERESTS}

The authors have not declared any conflict of interests.

\section{ACKNOWLEDGEMENTS}

The authors greatly acknowledge the women gardening center of Ouagadougou (AMIFOB) for their contributions during data collection.

\section{REFERENCES}

Arunachalam A, Khan ML, Singh ND (2003). Germination, growth and biomass accumulation as influenced by seed size in Mesua ferrea L. . Turk. J. Bot. 27:343-348.

Aslam M, Farooq A, Raziya N, Umer R, Kazi TG, Nadeem M (2005). Mineral composition of Moringa oleifera leaves and pods from different regions of Punjab, Pakistan. Asian J. Plant Sci. 4:417-421.

Ayana A, Bekele E (1999). Multivariate analysis of morphological variation in sorghum (Sorghum bicolor (L.) Moench) germplasm from Ethiopia and Eritrea. Genet. Resour. Crop Evol. 46(3):273-284.

Ayerza R (2011). Seed yield components, oil content, and fatty acid composition of two cultivars of moringa (Moringa oleifera Lam.) growing in the Arid Chaco of Argentina. Ind. Crops Prod. 33:389-394.

Baalbaki RZ, Copeland LO (1997). Seed size, density and protein content effects on field performance of wheat. Seed Sci. Technol. 25(3):511-521.

Dangasuk OG, Seurei P, Gudu S (1997). Genetic variation in seed and seedling traits in 12 African provenances of Faidherbia albida (del.) A. Chev. at Lodwar, Kenya. Agroforestry. Syst. 37:133-141.

Edward E, Shabani AOC, Yonika MN, Mathew AM (2014). Survival, growth and biomass production of Moringa oleifera provenances at Gairo inland plateau and Ruvu Coastal Region in Tanzania. Afr. J. Plant Sci. 8:54-64.

Farmer REJ (1997). Seed ecophysiology of temperate and boreal zone forest trees. St. Lucie Press, Delray Beach, FI.

Farris MA, Lechowicz MJ (1990). Functional ilnteractions among Traits that Determine Reproductive Success in a Native Annual Plant. Ecology 71:548-557.

Förster N, Ulrichs C, Schreiner M, Arndt N, Schmidt R, Mewis I (2015). Ecotype Variability in Growth and Secondary Metabolite Profile in Moringa oleifera: Impact of Sulfur and Water Availability. J. Agric. Food Chem. 63:2852-2861

Gamedze NP, Mupangwa JF, Bhebhe E, Dlamini BJ (2012). Growth performance and forage nutrient content of Moringa (Moringa oleifera Lam) provenances under Luyengo conditions, Swaziland conditions. UNISWA J. Agric. 16:41-48.

Hofmann M, Bütof A, Welk E, Bruelheide H (2013). Relationship between fundamental and realized niches with respect to frost and drought resistance. Preslia 85:1-17.

Ky-Dembele C, Tigabu M, Bayala J, Odén P (2014). Inter- and intraprovenances variations in seed size and seedling characteristics of Khaya senegalensis A. Juss in Burkina Faso. Agroforestry Syst. 88:311-320. 
Mendieta-Araica B, Spörndly E, Reyes-Sánchez N, Salmerón-Miranda F, Halling M (2013). Biomass production and chemical composition of Moringa oleifera under different planting densities and levels of nitrogen fertilization. Agroforest. Syst. 87:81-92.

Nyoka B, Roshetko J, Jamnadass R, Muriuki J, Kalinganire A, Lillesø JP, Beedy T, Cornelius J (2015). Tree Seed and Seedling Supply Systems: A Review of the Asia, Africa and Latin America Models. Small-scale Forest. 14:171-191.

Pallo FJP, Zombré NP, Sedogo MP (2009). Statut de la matière organique des sols de la zone nord soudanienne au Burkina Faso. Biotech. Agron. Soc. Environ. 13:139-142.

Pellis A, Laureysens I, Ceulemans R (2004). Growth and production of a short rotation coppice culture of poplar I. Clonal differences in leaf characteristics in relation to biomass production. Biomass Bioenergy 27:9-19.

Popoola JO, Obembe OO (2013). Local knowledge, use pattern and geographical distribution of Moringa oleifera Lam. (Moringaceae) in Nigeria. J. Ethnopharmacol. 150:682-691.

Quinn GP, Keough MJ (2002). Experimental design and data analysis for biologists. University Press, Cambridge, UK.

Roxas AU, Zizzo GV, Agnello S, Sciortino A, lapichino G (1994). Effect of seed storage and seed size on germination, emergence and bulblet production of Amaryllis belladonna L. Acta Hortic. (ISHS) 362:281-288.
SAS Institute Inc. (2012). Clustering data - using the cluster platform. $\mathrm{JM}{ }^{\circledR} 10$ Modeling and multivariate methods. SAS Institute Inc., Cary, NC, USA. Pp. 467-488.

Shahzad UM, Khan A, Jaskani M, Khan I, Korban S (2013). Genetic diversity and population structure of Moringa oleifera. Conserv. Genet. 14:1161-1172.

Singh B, Bhatt BP, Prasad P (2006). Variation in Seed and Seedling Traits of Celtis australis, a Multipurpose Tree, in Central Himalaya, India. Agroforest. Syst. 67:115-122.

Weih M, Nordh NE (2005). Determinants of biomass production in hybrid willows and prediction of field performance from pot studies. Tree Physiol. 25:1197-1206.

Wolde-Mieskel E, Sinclair FL (2000). Growth variability in a Senegalese provenance of Acacia nilotica ssp. tomentosa. Agroforest. Syst. 48:207-213. 